\title{
KINETICS OF PHOSPHORUS SORPTION IN SOILS IN THE STATE OF PARAÍBA(1)
}

\author{
Hemmannuella Costa Santos ${ }^{(2)}$, Fábio Henrique Tavares de \\ Oliveira $^{(3)}$, Ignácio Hernan Salcedo ${ }^{(4)}$, Adailson Pereira de Souza ${ }^{(4)} \&$ \\ Valério Damásio da Mota Silva ${ }^{(5)}$
}

\begin{abstract}
SUMMARY
The soil $P$ sorption capacity has been studied for many years, but little attention has been paid to the rate of this process, which is relevant in the planning of phosphate fertilization. The purpose of this experiment was to assess kinetics of $P$ sorption in 12 representative soil profiles of the State of Paraíba (Brazil), select the best data fitting among four equations and relate these coefficients to the soil properties. Samples of 12 soils with wide diversity of physical, chemical and mineralogical properties were agitated in a horizontal shaker, with $10 \mathrm{mmo} \mathrm{\textrm {L } ^ { - 1 }}$ $\mathrm{CaCl}_{2}$ solution containing 6 and $60 \mathrm{mg} \mathrm{L}^{-1} \mathrm{P}$, for periods of $5,15,30,45,60,90,120$, $420,720,1,020$, and $1,440 \mathrm{~min}$. After each shaking period, the $P$ concentration in the equilibrium solution was measured and three equations were fitted based on the Freundlich equation and one based on the Elovich equation, to determine which soil had the highest sorption rate (kinetics) and which soil properties correlated to this rate. The kinetics of $P$ sorption in soils with high maximum $P$ adsorption capacity (MPAC) was fast for $30 \mathrm{~min}$ at the lower initial $\mathrm{P}$ concentration (6 $\left.\mathrm{mg} \mathrm{L}^{-1}\right)$. No difference was observed between soils at the higher initial $P$ concentration $\left(60 \mathrm{mg} \mathrm{L}^{-1}\right)$. The $\mathrm{P}$ adsorption kinetics were positively correlated with clay content, MPAC and the amount of Al extracted with dithionite-citratebicarbonate. The data fitted well to Freundlich-based equations equation, whose coefficients can be used to predict $P$ adsorption rates in soils.
\end{abstract}

Index terms: Adsorption, kinetic equations, phosphate, tropical soils, semi-arid soils.

\footnotetext{
(1) Part of Doctoral Thesis of the first author presented to the Federal University of Paraiba, UFPB. Received for publication in July 28, 2010 and approved in April 5, 2011.

(2) Professor of Federal University of Paraiba (UFPB), Campus III, CEP 58220-000 Bananeiras (PB). E-mail: hecosantos@yahoo.com.br

(3) Professor of Federal Rural University of Semiarid (UFERSA). CEP 59625-900 Mossoró (RN). E-mail: fabio@ufersa.edu.br

(4) Professor of Federal University of Paraiba (UFPB), Campus II, CEP 58397-000 Areia (PB). E-mail: salcedo@ufpe.br

${ }^{(5)}$ Graduate student of Agronomy, Federal University of Paraíba (UFPB). E-mail: valerio_dms@hotmail.com
} 


\title{
RESUMO: CINÉTICA DE SORÇÃO DE FÓSFORO EM SOLOS DO ESTADO DA PARAÍBA
}

\begin{abstract}
A capacidade de sorção de P em solos tem sido estudada por muitos anos, mas pouca atenção foi dada à velocidade com que esse processo se realiza, sendo essa informação importante para o planejamento da adubação fosfatada. Objetivou-se, com este experimento, avaliar a cinética de sorção do P em 12 solos representativos do Estado da Paraíba, escolher o melhor ajuste dos dados entre quatro equações e relacionar os coeficientes dessas equações com características dos solos. Amostras de 12 solos com ampla variação de características físicas, químicas e mineralógicas foram agitadas horizontalmente com soluções de $\mathrm{CaCl}_{2} 10 \mathrm{mmo} \mathrm{L}^{-1}$ contendo 6 e $60 \mathrm{mg} \mathrm{L}^{-1}$ de P, pelos períodos de 5, 15, 30, 45, 60, 90, 120, 420, 720, 1.020 e $1.440 \mathrm{~min}$. Após cada período de agitação, mediu-se a concentração de $P$ na solução de equilíbrio e foram ajustadas três equações baseadas na equação de Freundlich e uma baseada na equação de Elovich, visando determinar qual solo apresentava maior taxa (cinética) de sorção e quais características dos solos se correlacionavam com essa taxa. A cinética de sorção de P nos solos com elevada CMAP foi rápida até os 30 min na menor concentração inicial de $P\left(6 \mathrm{mg} \mathrm{L}^{-1}\right)$, não sendo possível distinguir muitas diferenças entre os solos na maior concentração inicial de $P\left(60 \mathrm{mg} \mathrm{L}^{-1}\right)$. A velocidade com que o $P$ foi sorvido correlacionou-se positivamente com o teor de argila, com a capacidade máxima de adsorção de fosfato dos solos e com o teor de Al extraído por ditionito-citrato-bicarbonato. Os dados ajustaram-se bem às equações baseadas na equação de Freundlich, cujos coeficientes podem ser utilizados para predizer a taxa de sorção de P nos solos.
\end{abstract}

Termos para indexação: adsorção, equações cinéticas, fosfato, solos tropicais, solos do semiárido.

\section{INTRODUCTION}

The process of soil $\mathrm{P}$ sorption has been widely studied over the last few years, particularly because physicochemical adsorption to soil surfaces is the main process underlying phosphate retention, resulting in low P availability (Barrow, 1974; Agbenin \& Tiessen, 1994; Novais \& Smyth, 1999; Farias et al., 2009). Adsorption and precipitation reactions begin immediately after P addition to the soil. In acid soils, part of the $\mathrm{P}$ is adsorbed by secondary minerals of the clay fraction (mostly $\mathrm{Fe}$ and $\mathrm{Al}$ oxyhydroxides), and another part is precipitated with $\mathrm{Fe}$ and $\mathrm{Al}$ ions into soil solution, $\mathrm{FePO}_{4} \cdot 2 \mathrm{H}_{2} \mathrm{O}$ and $\mathrm{AlPO}_{4} \cdot 2 \mathrm{H}_{2} \mathrm{O}$, respectively. In soils where the $\mathrm{pH}$ is high, as in the case of several soils in the semi-arid region of northeastern Brazil, a small portion of this soil-applied $\mathrm{P}$ is adsorbed to the surface of secondary minerals of the clay fraction (with increased occurrence of $2: 1$ and 1:1 clay minerals and low content of $\mathrm{Fe}$ and $\mathrm{Al}$ oxyhydroxides), while the major portion is precipitated with $\mathrm{Ca}^{2+}$ of the soil solution, forming hydroxyapatite $\left(\mathrm{Ca}_{5}\left(\mathrm{PO}_{4}\right)_{3} \mathrm{OH}\right)$ (Novais \& Smyth, 1999). The set of these simultaneous adsorption and precipitation reactions of soil $\mathrm{P}$ is called soil $\mathrm{P}$ sorption (Sparks, 1995; Novais \& Smyth, 1999; Sims \& Pierzynski, 2005; Farias et al., 2009). Soil P sorption is a twostage process. In the first stage, $\mathrm{P}$ applied to the soil is rapidly adsorbed, most of it in the first hour of contact with soil. In the second and slower phase, the recently adsorbed $\mathrm{P}$ is more strongly retained in the soil, forming non-labile $\mathrm{P}$ (Gonçalves et al., 1985).
The pace at which $\mathrm{P}$ is sorbed, not only to the soil but also to other materials, has been the subject of several studies around the world, primarily to understand this phenomenon, which is a matter of great concern, and secondly to estimate the capacity and rate of various materials in removing excessive $\mathrm{P}$ amounts that cause pollution in the environment. (Karaca et al., 2004; Cheung \& Venkitachalam, 2006; Guan et al., 2007; Luengo et al., 2007; Wang et al., 2009). Numerous studies in Brazil have looked into the process of $\mathrm{P}$ sorption as related to the amount of $\mathrm{P}$ adsorbed (Pereira \& Faria, 1998; Moreira et al., 2006; Chaves et al., 2007; Farias et al., 2009), but few studies focused on the sorption process over time, which was addressed in the studies of Singh et al. (1983), Gonçalves et al. (1985) and Reis et al. (1995). The importance of these studies lies in the fact that the faster the process of $\mathrm{P}$ sorption to soil surfaces, the lower the amount of plant-available $\mathrm{P}$ in short periods.

Several equations, most of them empirical, were used to describe the process of $\mathrm{P}$ sorption over time, leading to some inexplicable results, or difficulties in the adjustments for some materials or soils (Karaca et al., 2004; Cheung \& Venkitachalam, 2006; Guan et al., 2007). This was also caused by the great heterogeneity of soils in chemical, physical and mineralogical properties in the solid state and also regarding soil solution (Reis et al., 1995). Moreover, the relative simplicity of the equations makes it difficult to describe the complex sequence of steps of the fast and slow sorption stages (Cheung \& 
Venkitachalam, 2006). The equations proposed by Kuo \& Lotse (1974), Barrow \& Shaw (1975), Panda et al. (1978) and Chien \& Clayton (1980) are widely used.

To date, the studies of Singh et al. (1983), Gonçalves et al. (1985) and Reis et al. (1995) are the only conducted in Brazil on adsorption kinetics of soil P. Results indicate fast $\mathrm{P}$ sorption in tropical soils, particularly in the most developed Cerrado soils. However, no studies on the referred subjected investigated soils of the Brazilian northeast, in particular, soils of the State of Paraíba. The purpose of this study was to assess the $\mathrm{P}$ adsorption kinetics in soils in the state of Paraíba, select the best fit of data among four equations and relate the coefficients of these equations to the soil chemical properties.

\section{MATERIALS AND METHODS}

Soil samples from the $0-30 \mathrm{~cm}$ layer of 12 representative soil profiles of the State of Paraíba were used (Oliveira et al., 2006), representing 11 suborders of the Brazilian Soil Classification System (chemical, physical and mineralogical properties are shown in table 1. The soil samples were classified as (Embrapa, 2006): Neossolo Regolitico (RR); Neossolo Litólico (RL); Argissolo Acinzentado (PAC); Neossolo Flúvico (RY); Argissolo Amarelo (PA); Latossolo Amarelo (LA); Luvissolo Háplico (TX); Planossolo Háplico (SX); Argissolo Vermelho Amarelo (PVA); Argissolo Vermelho eutrófico (PVe); Argissolo Vermelho distrófico (PVd) and Vertissolo Háplico (VX).

The need for liming (PA, PAC, PVA, and PVd) was estimated by base saturation (V), and when necessary a mixture of $\mathrm{CaCO}_{3}$ (p.a.) $+\mathrm{MgCO}_{3}$ (p.a.), at a molar ratio 4:1 was applied to the soil. The 12 soil samples were incubated in plastic bags for two weeks with an amount of water corresponding to $50 \%$ of the total porosity and then ready for the laboratory experiment of $\mathrm{P}$ sorption kinetics.

The factors studied for each soil were two initial concentrations of dissolved phosphate $\left(6\right.$ and $\left.60 \mathrm{mg} \mathrm{L}^{-1}\right)$ and 11 equilibrium periods $(5,15,30,45,60,90,120$, 420, 720, 1,020 and 1,440 min) of the solutions containing $\mathrm{P}$ with the soil samples. The experiment was arranged in a completely randomized design with three replications.

Table 1. Chemical, physical and mineralogical properties of 12 representative soil profiles in the State of Paraíba $^{(1)}$

\begin{tabular}{|c|c|c|c|c|c|c|c|c|c|c|c|c|}
\hline \multirow{2}{*}{ Property } & \multicolumn{12}{|c|}{ Soil $^{(2)}$} \\
\hline & $\mathbf{R R}$ & RL & PAC & $\mathbf{R Y}$ & PA & LA & $\mathbf{T X}$ & SX & PVA & PVe & PVd & VX \\
\hline $\mathrm{pH}\left(\mathrm{H}_{2} \mathrm{O}\right)$ & 7.0 & 6.2 & 4.4 & 7.3 & 5.9 & 5.9 & 6.2 & 7.2 & 5.5 & 6.3 & 5.0 & 8.4 \\
\hline $\mathrm{CO}\left(\mathrm{g} \mathrm{kg}^{-1}\right)$ & 3.4 & 3.8 & 10.7 & 8.9 & 3.5 & 5.9 & 7.6 & 4.3 & 10.7 & 9.0 & 8.0 & 3.7 \\
\hline P-rem $\left(\mathrm{mg} \mathrm{L}^{-1}\right)^{(3)}$ & 54 & 45 & 47 & 44 & 45 & 44 & 41 & 37 & 28 & 35 & 28 & 25 \\
\hline $\operatorname{MPAC}\left(\mathrm{mg} \mathrm{g}^{-1}\right)^{(4)}$ & 0.036 & 0.130 & 0.144 & 0.172 & 0.174 & 0.176 & $\begin{array}{ll}6 & 0.177\end{array}$ & 0.248 & 0.288 & 0.297 & 0.347 & 0.435 \\
\hline $\left.\mathrm{P}(\mathrm{mg} \mathrm{dm})^{-3}\right)$ & 24.07 & 4.31 & 3.59 & 144.33 & 1.52 & 11.42 & 4.35 & 21.58 & 2.63 & 6.80 & 2.32 & 19.77 \\
\hline $\mathrm{K}^{+}\left(\mathrm{mmol}_{\mathrm{c}} \mathrm{dm}^{-3}\right)$ & 1.8 & 1.9 & 1.0 & 6.0 & 0.4 & 1.8 & 6.4 & 2.1 & 2.4 & 3.9 & 1.9 & 6.9 \\
\hline $\mathrm{Ca}^{2+}\left(\mathrm{mmol}_{\mathrm{c}} \mathrm{dm}^{-3}\right)$ & 18.0 & 20.0 & 8.0 & 110.0 & 6.0 & 16.0 & 61.0 & 122.0 & 11.0 & 54.0 & 19.0 & 291.0 \\
\hline $\mathrm{Mg}^{2+}\left(\mathrm{mmol}_{\mathrm{c}} \mathrm{dm}^{-3}\right)$ & 9.0 & 11.0 & 6.0 & 40.0 & 4.0 & 11.5 & 40.0 & 56.0 & 13.0 & 18.0 & 8.0 & 104.0 \\
\hline $\mathrm{Na}^{+}\left(\mathrm{mmol}_{\mathrm{c}} \mathrm{dm}^{-3}\right)$ & 0.2 & 2.5 & 0.5 & 0.9 & 0.2 & 1.1 & 1.0 & 3.0 & 0.4 & 0.4 & 0.4 & 21.9 \\
\hline $\mathrm{Al}^{3+}\left(\mathrm{mmol}_{\mathrm{c}} \mathrm{dm}^{-3}\right)$ & 0.0 & 0.5 & 9.6 & 0.0 & 1.1 & 0.0 & 0.0 & 0.0 & 3.2 & 0.0 & 3.2 & 0.0 \\
\hline$(\mathrm{H}+\mathrm{Al})\left(\mathrm{mmol}_{\mathrm{c}} \mathrm{dm}^{-3}\right)$ & 10.7 & 22.9 & 56.7 & 12.2 & 16.8 & 21.4 & 29.0 & 15.3 & 55.0 & 27.5 & 42.8 & 7.6 \\
\hline CEC efetiva $\left(\mathrm{mmol}_{\mathrm{c}} \mathrm{dm}^{-3}\right)$ & 29.0 & 35.9 & 24.9 & 156.9 & 11.7 & 30.4 & 108.9 & 183.1 & 30.0 & 76.3 & 32.4 & 423.7 \\
\hline $\operatorname{CEC~}\left(\mathrm{mmol}_{c} \mathrm{dm}^{-3}\right)$ & 39.7 & 58.3 & 72.0 & 169.1 & 27.4 & 51.8 & 137.4 & 198.4 & 81.8 & 103.8 & 72.0 & 431.3 \\
\hline $\mathrm{V}(\%)$ & 73 & 61 & 21 & 93 & 39 & 59 & 79 & 92 & 33 & 74 & 41 & 98 \\
\hline Clay $\left(\mathrm{g} \mathrm{kg}^{-1}\right)$ & 30 & 80 & 120 & 200 & 90 & 290 & 140 & 190 & 230 & 180 & 380 & 430 \\
\hline Moisture equi. $\left(\mathrm{kg} \mathrm{kg}^{-1}\right)$ & 0.04 & 0.06 & 0.06 & 0.19 & 0.07 & 0.12 & 0.11 & 0.14 & 0.12 & 0.12 & 0.18 & 0.34 \\
\hline $\mathrm{Fe}_{\mathrm{d}}\left(\mathrm{g} \mathrm{kg}^{-1}\right)^{(5)}$ & 0.71 & 2.13 & 2.02 & 5.05 & 3.84 & 7.63 & 4.69 & 11.5 & 9.54 & 12.94 & 7.63 & 6.74 \\
\hline $\mathrm{Fe}_{\mathrm{o}}\left(\mathrm{g} \mathrm{kg}^{-1}\right)^{(6)}$ & 0.17 & 0.66 & 0.18 & 1.09 & 0.13 & 0.25 & 0.79 & 0.66 & 0.84 & 2.73 & 0.25 & 0.97 \\
\hline $\mathrm{Al}_{\mathrm{d}}\left(\mathrm{g} \mathrm{kg}_{-}{ }^{-1}\right)^{(5)}$ & 0.04 & 0.21 & 1.08 & 0.29 & 0.94 & 1.12 & 0.38 & 0.42 & 1.61 & 1.47 & 1.12 & 0.54 \\
\hline $\mathrm{Al}_{\mathrm{o}}\left(\mathrm{g} \mathrm{kg}^{-1}\right)^{(6)}$ & 0.04 & 0.16 & 0.27 & 0.27 & 0.27 & 0.33 & 0.33 & 0.33 & 0.62 & 0.68 & 0.33 & 1.03 \\
\hline Minerals $^{(7)}$ & $\begin{array}{l}\mathrm{Ct}, \mathrm{Mi}, \mathrm{Qz}, \\
\quad(2: 1)\end{array}$ & $\begin{array}{c}\mathrm{Mi}, \mathrm{Ct} \\
(2: 1)\end{array}$ & $\begin{array}{l}\mathrm{Ct} \\
\mathrm{Gt}\end{array}$ & $\begin{array}{l}\mathrm{Mi}, \mathrm{Ct}, \\
(2: 1)\end{array}$ & $\begin{array}{c}\mathrm{Ct}, \mathrm{Gb}, \\
\mathrm{Gt}\end{array}$ & $\begin{array}{l}\mathrm{Ct} \\
\mathrm{Gt}\end{array}$ & $\begin{array}{l}\mathrm{Ct}, \mathrm{Mi}, \\
(2: 1), \mathrm{Fp}\end{array}$ & $\begin{array}{c}(2: 1), \mathrm{Mi}, \\
\mathrm{Ct}, \mathrm{Gt}\end{array}$ & $\begin{array}{l}\mathrm{Ct} \\
\mathrm{Gt}\end{array}$ & $\begin{array}{c}\mathrm{Ct}, \mathrm{Gt}, \mathrm{Mi}, \\
(2: 1)\end{array}$ & $\begin{array}{l}\mathrm{Ct}, \mathrm{Gt}, \\
\mathrm{Mi}, \mathrm{Hm}\end{array}$ & $\begin{array}{c}(2: 1), \mathrm{Qz}, \\
\mathrm{Mi}\end{array}$ \\
\hline Sampling location & $\begin{array}{l}\text { Espe- } \\
\text { rança }\end{array}$ & $\begin{array}{l}\text { Sole- } \\
\text { dade }\end{array}$ & $\begin{array}{l}\text { Maman- } \\
\text { guape }\end{array}$ & - Souza & Conde & Cuité & $\begin{array}{l}\text { São Migu } \\
\text { de Taipú }\end{array}$ & uel Cuité & Areia & $\begin{array}{l}\text { Marizó- } \\
\text { polis }\end{array}$ & $\begin{array}{l}\text { Alagoa } \\
\text { Grande }\end{array}$ & Souza \\
\hline
\end{tabular}

(1) According to analytical methods described in Embrapa (1997). Data shown in Farias et al. (2009). (2) According to the Brazilian Soil Classification System (Embrapa, 2006): RR: Neossolo Regolítico, RL: Neossolo Litólico, PAC: Argissolo Acinzentado, RY: Neossolo Flúvico, PA: Argissolo Amarelo, LA: Latossolo Amarelo, TX: Luvissolo Háplico, SX: Planossolo Háplico, PVA: Argissolo Vermelho-Amarelo; PVe: Argissolo Vermelho eutrófico, PVd: Argissolo Vermelho distrófico, VX: Vertissolo Háplico. (3) Remaining phosphorus (Alvarez V. et al., 2000). ${ }^{(4)}$ Maximum phosphate adsorption capacity. ${ }^{(5) I}$ Iron and aluminum oxides extracted with dithionite-citrate-bicarbonate. ${ }^{(6)}$ Iron and aluminum oxides extracted with ammonium oxalate. ${ }^{(7)}$ Predominant minerals in clay fraction. Ct: kaolinite; Gb: gibbsite; Gt: goethite; Mi: mica; (2:1) layer type clay mineral 2:1; Hm: hematite; Qz: quartz; Fp: feldspar. 
Of each sample, $2.1 \mathrm{~g}$ soil was placed in an $125 \mathrm{~mL}$ Erlenmeyer flask and horizontally shaken with 25 $\mathrm{mL}$ of $\mathrm{CaCl}_{2} 10 \mathrm{mmo} \mathrm{L}^{-1}$ solution containing 6 or $60 \mathrm{mg} \mathrm{L}^{-1}$ of $\mathrm{P}$ in the form of $\mathrm{KH}_{2} \mathrm{PO}_{4}$. Two drops of chloroform were added to suppress biological activity. At the end of each equilibrium period, the suspensions were filtered and the final $\mathrm{P}$ concentration in the equilibrium solution was determined, according to Braga \& Defelipo (1974). The amount of $\mathrm{P}$ adsorbed in each soil was calculated by the difference between the $\mathrm{P}$ concentration in the equilibrium solution at the beginning and end of the shaking period.

In order to assess the kinetics of $\mathrm{P}$ sorption, the equations suggested by Kuo \& Lotse (1974); Barrow \& Shaw (1975); Panda et al. (1978) and Chien \& Clayton (1980) were used.

The equation of Kuo \& Lotse (1974) originated from a modification of the Freundlich equation making it time-dependent: $\mathrm{X}=\mathrm{K} \mathrm{Cot}^{1 / \mathrm{m}}$, where $\mathrm{X}$ is the amount of $\mathrm{P}$ adsorbed ( $\left.\mathrm{mg} \mathrm{g}^{-1}\right)$, Co is the initial $\mathrm{P}$ concentration $\left(\mathrm{mg} \mathrm{L}^{-1}\right), \mathrm{K}$ represents the reaction rate $\left(\mathrm{min}^{-1}\right)$ and $\mathrm{m}$ is a constant.

Barrow \& Shaw (1975) combined an empirical equation with the Freundlich isothermal equation to study the change rate in the phosphate concentration of the equilibrium solution: $\mathrm{X}=\mathrm{K} \mathrm{C}^{\mathrm{m}} \mathrm{t}^{\mathrm{n}}$, in this case, $\mathrm{X}$ is the amount of $\mathrm{P}$ adsorbed $\left(\mathrm{mg} \mathrm{kg}^{-1}\right), \mathrm{K}$ is the reaction rate $\left(\mathrm{mg} \mathrm{kg}^{-1} \mathrm{~min}^{-1}\right), \mathrm{C}$ is the concentration at time $t\left(\mathrm{mg} \mathrm{L}^{-1}\right)$, $\mathrm{t}$ is the time ( $\mathrm{min}$ ) and $\mathrm{m}$ and $\mathrm{n}$ are constants related to the sorption rate.

Panda et al. (1978) suggested the equation: $\mathrm{C}=$ K.t. ${ }^{-n}$, where $\mathrm{C}$ is the phosphate concentration $\left(\mathrm{mg} \mathrm{L}^{-1}\right)$ measured in time $\mathrm{t}$ (min), the constant $\mathrm{K}$ denotes a $\mathrm{P}$ concentration in the equilibrium solution $\left(\mathrm{mg} \mathrm{L}^{-1}\right)$ and the index is related to the phosphate sorption rate in soil.

Chien \& Clayton (1980) modified the equation of Elovich and used it to assess the kinetics of phosphate adsorption and desorption in soils: $q=(\alpha \beta)^{(1 / \beta)} t^{(1 / \beta)}$, q: adsorbed $\mathrm{P}$ and $\mathrm{a}$ and $\mathrm{b}$ are constants used to compare the reaction rates.

The coefficients of the equations were estimated by non-linear regression (Gauss-Newton), using the SAEG (2007) statistical package, and tested by the F test.

The identification of the best equation fitting was based on AIC (Akaike's Information Criterion) developed by Akaike (1974). The AIC is a test of equations aimed to select the best, i..e, the equation with lowest AIC. The AIC is defined by the equation: $\mathrm{AIC}=2 \mathrm{k}+\mathrm{n}[\ln \mathrm{SQR} / \mathrm{n})]$, where $\mathrm{k}$ is the number of coefficients of the equation, $\mathrm{n}$ is the number of observations and SQR is the sum of the square of residuals. Since a small number of observations were obtained in the present study, the corrected AIC (AICc) was used, which is defined as: $\mathrm{AICc}=\mathrm{AIC}+[2 \mathrm{k}(\mathrm{k}+1) /$ $\mathrm{n}-\mathrm{k}-1]$, where $\mathrm{k}$ is the number of coefficients of the equation plus one and $\mathrm{n}$ is the number of observations. Correlation analyses between the values of the coefficients of these equations and the values of the chemical and physical properties of the soils with the soil P sorption capacity (FCP) were carried out.

\section{RESULTS AND DISCUSSION}

The $\mathrm{P}$ concentration in the equilibrium solution, as related to the shaking time of $\mathrm{P}$ with soil solution and on $\mathrm{P}$ concentration ( 6 and $60 \mathrm{mg} \mathrm{L}^{-1}$ ), is shown in Table 2. The sorption process was performed in two phases, a fast and a slow one, when equilibrium is reached, as widely reported in the literature (Barrow \& Shaw, 1975; Singh et al., 1983; Gonçalves et al., 1985; Reis et al., 1995; Karaca et al., 2004; Cheung \& Venkitachalan, 2006; Guan et al., 2007; Wang et al., 2009). The decrease in $P$ sorption rate over time suggests that factors such as the penetration of $\mathrm{P}$ into the pores of soil microaggregates and the $\mathrm{P}$ saturation of the adsorbent surface hamper $\mathrm{P}$ sorption for each increment of soil P application (Cheung \& Venkitachalam, 2006).

When the solution containing $6 \mathrm{mg} \mathrm{L}^{-1} \mathrm{P}$ was equilibrated with the soils, the PVe, PVA, PVd, SX and VX adsorbed approximately $75 \%$ of the $\mathrm{P}$ in the equilibrium solution in up to $45 \mathrm{~min}$, which lasted up to $1,020 \mathrm{~min}$ in the PA, PAC, LA, RR, RL, TX and RY soils (Table 2). Similar results were obtained by Singh et al. (1983) in soils in the Amazon and by Gonçalves et al. (1985) and Reis et al. (1995) in soils of the state of Minas Gerais. In soils of the Amazon forest, the fastest adsorption phase, to adsorb $85 \%$ of the P, lasted up to two days, (Singh et al., 1983); in soils of Minas Gerais, Gonçalves et al. (1985) observed that $75 \%$ of the adsorption was completed in up to 30 min for the soils with higher MPAC and in up to 12 hours for soils with lowest MPAC. Reis et al. (1995) found that the fastest soil $\mathrm{P}$ sorption phase lasted 3090 min, to adsorb on average $50 \%$ of the $\mathrm{P}$ in the equilibrium solution.

It is worth stressing that PVd and VX adsorbed 74 and $80 \%$ of the $6 \mathrm{mg} \mathrm{L}^{-1} \mathrm{P}$ added within only $5 \mathrm{~min}$, possibly due to the high clay contents (380 and $\left.430 \mathrm{~g} \mathrm{~kg}^{-1}\right)$ and high MPAC (0.3473 and $\left.0.4353 \mathrm{mg} \mathrm{g}^{-1}\right)$, respectively (Table 1 ). It is possible that the precipitation process plays a significant role in $\mathrm{P}$ adsorption in the soils VX and SX, due to the high values of $\mathrm{pH}$ and $\mathrm{Ca}^{2+}$ associated to low contents of $\mathrm{Fe}$ and $\mathrm{Al}$ oxides (Table 1 ). In calcareous soils, which also have high $\mathrm{pH}$ and $\mathrm{Ca}^{2+}$, values, Cheung \& Venkitachalam (2006) also detected fast $\mathrm{P}$ sorption in the first $\mathrm{P}$ - soil contact periods.

At the end of the shaking time, RY soil had adsorbed the smallest $\mathrm{P}$ amount, probably because this soil had a higher initial content of available $\mathrm{P}$ (144 $\left.\mathrm{mg} \mathrm{dm}^{-3}\right)$ and a low MPAC value $\left(0.1728 \mathrm{mg} \mathrm{g}^{-1}\right)$, which must have saturated the sorption sites. P sorption in soils of the State of Rio Grande do Norte 
Table 2. Average $P$ concentration in the equilibrium solution as related to the equilibrium time and the initial $P$ concentration in 12 representative soil profiles of the state of Paraíba

\begin{tabular}{|c|c|c|c|c|c|c|c|c|c|c|c|}
\hline \multirow{2}{*}{ Soil $^{(1)}$} & \multicolumn{11}{|c|}{ Equilibrium time (min) } \\
\hline & 5 & 15 & 30 & 45 & 60 & 90 & 120 & 420 & 720 & 1020 & 1440 \\
\hline & \multicolumn{11}{|c|}{$\mathrm{mg} \mathrm{L}^{-1}-$} \\
\hline $\mathrm{RR}$ & 5.63 & 5.10 & 4.83 & 5.09 & 5.20 & 4.91 & 5.18 & 3.06 & 3.14 & 1.75 & 1.00 \\
\hline RL & 4.74 & 3.82 & 3.94 & 3.29 & 3.32 & 3.00 & 3.06 & 1.27 & 0.94 & 0.68 & 0.35 \\
\hline PAC & 5.38 & 4.71 & 4.27 & 3.90 & 3.54 & 3.33 & 3.23 & 1.84 & 1.44 & 0.64 & 0.23 \\
\hline RY & 3.81 & 3.71 & 3.19 & 2.88 & 2.75 & 2.68 & 2.72 & 1.79 & 1.94 & 1.71 & 1.28 \\
\hline PA & 4.34 & 3.37 & 3.03 & 2.40 & 2.03 & 1.68 & 1.58 & 0.15 & 0.15 & 0.11 & 0.06 \\
\hline LA & 4.05 & 3.36 & 2.75 & 2.28 & 2.29 & 2.11 & 2.06 & 0.83 & 0.67 & 0.31 & 0.17 \\
\hline TX & 3.89 & 3.12 & 2.88 & 2.33 & 2.19 & 1.87 & 2.04 & 0.94 & 0.98 & 0.56 & 0.27 \\
\hline SX & 2.61 & 1.78 & 1.73 & 1.57 & 1.30 & 1.19 & 1.15 & 0.41 & 0.51 & 0.26 & 0.26 \\
\hline PVA & 2.49 & 1.73 & 1.17 & 0.83 & 0.60 & 0.60 & 0.60 & 0.50 & 0.13 & 0.12 & 0.11 \\
\hline PVe & 2.87 & 2.05 & 1.69 & 1.53 & 1.25 & 1.35 & 1.06 & 0.64 & 0.42 & 0.34 & 0.16 \\
\hline PVd & 1.56 & 1.22 & 0.78 & 0.77 & 0.62 & 0.37 & 0.34 & 0.33 & 0.15 & 0.06 & 0.12 \\
\hline \multirow[t]{2}{*}{ VX } & 1.17 & 0.66 & 0.46 & 0.43 & 0.40 & 0.29 & 0.23 & 0.17 & 0.09 & 0.17 & 0.07 \\
\hline & \multicolumn{11}{|c|}{ Initial $\mathrm{P}$ concentration of $60 \mathrm{mg} \mathrm{L}^{-1}$} \\
\hline $\mathrm{RR}$ & 60.8 & 59.7 & 60.6 & 59.5 & 59.2 & 58.1 & 57.4 & 59.1 & 60.9 & 54.4 & 56.0 \\
\hline RL & 54.5 & 55.4 & 53.6 & 52.4 & 53.0 & 53.6 & 54.1 & 52.4 & 51.9 & 48.3 & 46.2 \\
\hline $\mathrm{PAC}$ & 57.0 & 53.9 & 53.6 & 53.6 & 51.5 & 53.1 & 53.9 & 53.9 & 49.5 & 50.9 & 45.4 \\
\hline $\mathrm{RY}$ & 53.0 & 54.0 & 50.1 & 50.4 & 51.5 & 51.3 & 52.6 & 48.6 & 52.2 & 48.5 & 50.6 \\
\hline PA & 57.3 & 51.8 & 52.6 & 50.6 & 49.6 & 49.1 & 50.9 & 44.4 & 38.1 & 35.1 & 29.1 \\
\hline LA & 56.1 & 55.8 & 53.5 & 49.8 & 49.6 & 49.7 & 50.8 & 46.7 & 45.1 & 42.8 & 41.2 \\
\hline TX & 51.8 & 52.0 & 52.1 & 50.2 & 51.1 & 51.1 & 46.1 & 47.9 & 47.7 & 45.3 & 42.7 \\
\hline SX & 57.2 & 52.3 & 50.0 & 47.1 & 48.0 & 47.7 & 49.6 & 45.9 & 42.9 & 40.8 & 37.9 \\
\hline PVA & 50.4 & 45.3 & 43.6 & 43.8 & 41.9 & 38.2 & 38.4 & 36.0 & 34.3 & 30.8 & 28.4 \\
\hline $\mathrm{PVe}$ & 52.4 & 52.6 & 50.2 & 48.0 & 46.5 & 45.4 & 46.1 & 42.4 & 40.2 & 39.2 & 37.5 \\
\hline PVd & 44.4 & 45.3 & 43.8 & 39.9 & 38.9 & 38.4 & 37.2 & 34.8 & 34.8 & 32.1 & 30.1 \\
\hline VX & 37.2 & 36.5 & 32.2 & 30.6 & 30.6 & 32.8 & 29.1 & 27.6 & 27.8 & 25.8 & 27.1 \\
\hline
\end{tabular}

(1) RR: Neossolo Regolítico, RL: Neossolo Litólico, PAC: Argissolo Acinzentado, RY: Neossolo Flúvico, PA: Argissolo Amarelo, LA: Latossolo Amarelo, TX: Luvissolo Háplico, SX: Planossolo Háplico, PVA: Argissolo Vermelho-Amarelo; PVe: Argissolo Vermelho eutrófico, PVd: Argissolo Vermelho distrófico, VX: Vertissolo Háplico.

with characteristics similar to those of the soil studied here were also low (Godinho et al., 1997). High contents of soil $\mathrm{P}$ solution, as well as the previous $\mathrm{P}$ application, reduced the phosphate adsorption capacity of soils due to the formation of insoluble $\mathrm{Fe}$ and $\mathrm{Al}$ phosphates that reduce the maximum phosphate adsorption capacity (MPAC) of soils (Barrow, 1974).

At an initial $\mathrm{P}$ concentration of $60 \mathrm{mg} \mathrm{L}^{-1}$, the soils that had adsorbed most phosphate, at the end of $24 \mathrm{~h}$, were VX, PVA, PA and PVd, with an average adsorption of $50 \%$ of the $\mathrm{P}$ applied (Table 2). Likewise, at the lower initial $\mathrm{P}$ solution concentration, $\mathrm{RR}$ and $\mathrm{RY}$ had adsorbed less $\mathrm{P}$ at the end of the shaking time, approximately 7 and $16 \%$ of the applied $\mathrm{P}$, probably because of the lower clay content $\left(30 \mathrm{~g} \mathrm{~kg}^{-1}\right)$ and low MPAC (0.0360 $\left.\mathrm{mg} \mathrm{g}^{-1}\right)$ in RR and the higher initial soil $\mathrm{P}$ content $\left(144.33 \mathrm{mg} \mathrm{dm}^{-3}\right)$ in RY soil. In a study conducted by Cheung \& Venkitachalam (2006) with different materials, the sorption rate and amount of $\mathrm{P}$ extracted from the solution increased when the initial $\mathrm{P}$ concentration in the solution increased. In this study, in turn, there was a decrease in the sorption rate, proportional to the increase in the initial $\mathrm{P}$ concentration in the equilibrium solution.

In general, the data fit the equations proposed by Kuo \& Lotse (1974), Barrow \& Shaw (1975) and Panda (1978) (Table 3), but not the equation proposed by Chien \& Clayton (1980). Lack of fitting to the equation of Chien \& Clayton (1980) possibly occurred because the assumption of the equation $(\alpha \beta t>1)$ was not met. Thus, the data of the coefficient of this equation were not presented.

The lack of fitting to the equation proposed by Chien $\&$ Clayton (1980) is not consistent with the literature, since some authors consider this equation as better than the others (Torrent, 1987; Cheung \& Venkitachalam, 2006; Guan et al., 2007). However, Polyzopoulos et al. (1985) affirm that assumptions for the Elovich equation are not valid in all cases, because a considerable amount of phosphate can be adsorbed at higher or lower rates than the amount adsorbed at a rate that can be described by the equation, which possibly occurred in the present study. 
Table 3. Estimated values of the constants of equations that describe $P$ sorption in soil in relation to the soil$P$ contact time, at both initial $P$ concentrations in 12 representative soil profiles of the state of Paraíba

\begin{tabular}{|c|c|c|c|c|c|c|c|}
\hline \multirow{3}{*}{ Soil $^{(1)}$} & \multicolumn{7}{|c|}{ Coefficient } \\
\hline & \multicolumn{2}{|c|}{ Panda et al. (1978) } & \multicolumn{3}{|c|}{ Barrow \& Shaw (1975) ${ }^{(3)}$} & \multicolumn{2}{|c|}{ Kuo \& Lotse $(1974)^{(4}$} \\
\hline & $\mathbf{K}$ & $\mathbf{n}$ & $\mathbf{K}$ & $\mathbf{m}$ & $\mathbf{n}$ & $\mathbf{K}$ & M \\
\hline \multicolumn{8}{|c|}{ Initial $\mathrm{P}$ concentration of $6 \mathrm{mg} \mathrm{L}^{-1}$} \\
\hline $\mathrm{RR}$ & 8.3976 & 0.1602 & 0.0032 & -0.2345 & 0.3821 & 0.0001 & 1.9585 \\
\hline $\mathrm{RL}$ & 8.1259 & 0.2612 & 0.0083 & 0.0521 & 0.2717 & 0.0016 & 4.1289 \\
\hline PAC & 9.2989 & 0.2615 & 0.0056 & 0.0248 & 0.3237 & 0.0010 & 3.2599 \\
\hline RY & 5.3645 & 0.1631 & 0.0273 & -0.2273 & 0.0855 & 0.0030 & 7.6930 \\
\hline PA & 9.0422 & 0.3910 & 0.0113 & 0.1027 & 0.2768 & 0.0029 & 5.5803 \\
\hline LA & 7.3908 & 0.3155 & 0.0145 & 0.0564 & 0.2072 & 0.0030 & 6.0206 \\
\hline $\mathrm{TX}$ & 6.7133 & 0.2901 & 0.0182 & 0.0262 & 0.1615 & 0.0032 & 6.7049 \\
\hline $\mathrm{SX}$ & 4.5511 & 0.3193 & 0.0371 & 0.0118 & 0.0876 & 0.0054 & 12.1450 \\
\hline PVA & 5.5554 & 0.4789 & 0.0376 & -0.0037 & 0.0663 & 0.0062 & 14.5930 \\
\hline $\mathrm{PVe}$ & 5.1450 & 0.3405 & 0.0267 & 0.0664 & 0.1223 & 0.0051 & 11.1160 \\
\hline PVd & 3.2573 & 0.4202 & 0.0444 & -0.0081 & 0.0401 & 0.0073 & 22.4700 \\
\hline VX & 2.4477 & 0.4680 & 0.0507 & -0.0332 & 0.0125 & 0.0082 & 36.4200 \\
\hline \multicolumn{8}{|c|}{ Initial $\mathrm{P}$ concentration of $60 \mathrm{mg} \mathrm{L}^{-1}$} \\
\hline $\mathrm{RR}$ & 62.2094 & 0.0122 & $1.1 \times 10^{-35}$ & -21.091 & 0.1155 & $3.2 \times 10^{-6}$ & 1.3572 \\
\hline $\mathrm{RL}$ & 58.2574 & 0.0228 & 7038170.0 & -4.6831 & 0.0313 & 0.00052 & 5.5457 \\
\hline PAC & 58.9479 & 0.0252 & 3388473.0 & -4.5082 & 0.0376 & 0.00004 & 5.3654 \\
\hline RY & 53.8843 & 0.0109 & 25.7366 & -1.4682 & 0.0001 & 0.00109 & 16.1180 \\
\hline PA & 69.7598 & 0.0898 & 1.2487 & -0.9000 & 0.2279 & 0.0003 & 2.7274 \\
\hline LA & 62.6650 & 0.0523 & 660.9900 & -2.3831 & 0.0115 & 0.0005 & 4.1003 \\
\hline $\mathrm{TX}$ & 56.3293 & 0.0301 & 71955.3000 & -3.4734 & 0.0190 & 0.0009 & 6.6929 \\
\hline $\mathrm{SX}$ & 61.9454 & 0.0586 & 371.4100 & -2.1769 & 0.0729 & 0.0007 & 4.5962 \\
\hline PVA & 58.9412 & 0.0891 & 0.1811 & -0.7301 & 0.0985 & 0.0001 & 5.8652 \\
\hline $\mathrm{PVe}$ & 60.1576 & 0.0604 & 2738.8600 & -2.6186 & 0.0188 & 0.00009 & 5.3458 \\
\hline PVd & 52.2739 & 0.0682 & 23.9646 & -1.3306 & 0.0244 & 0.00194 & 8.1459 \\
\hline VX & 41.0258 & 0.0630 & 1.7461 & -1.1884 & -0.0070 & 0.00359 & 15.6100 \\
\hline
\end{tabular}

(1) RR: Neossolo Regolítico, RL: Neossolo Litólico, PAC: Argissolo Acinzentado, RY: Neossolo Flúvico, PA: Argissolo Amarelo, LA: Latossolo Amarelo, TX: Luvissolo Háplico, SX: Planossolo Háplico, PVA: Argissolo Vermelho-Amarelo, PVe: Argissolo Vermelho eutrófico, PVd: Argissolo Vermelho distrófico, VX: Vertissolo Háplico. ${ }^{(2)} \mathrm{C}=\mathrm{K} \mathrm{t}^{-\mathrm{n}}$, C: concentration in time t, K: constant related to $\mathrm{P}$ in the solution, $\mathrm{n}$ : constant related to the sorption rate. ${ }^{(3)} \mathrm{X}=\mathrm{K} \mathrm{C}^{\mathrm{m}} \mathrm{t}^{\mathrm{n}}, \mathrm{X}: \mathrm{P}$ adsorbed, $\mathrm{C}: \mathrm{P}$ concentration in time $\mathrm{t}, \mathrm{K}, \mathrm{m}$ and $\mathrm{n}$ are constant. ${ }^{(4)} \mathrm{X}=\mathrm{K} \mathrm{Co} \mathrm{t}^{1 / \mathrm{m}}, \mathrm{X}$ : $\mathrm{P}$ adsorbed, Co: initial $\mathrm{P}$ concentration, K: sorption rate, m: non-dimensional constant.

At the lower initial $\mathrm{P}$ concentration $\left(6 \mathrm{mg} \mathrm{L}^{-1}\right)$ the values of $\mathrm{n}$ (sorption rate) of the equation proposed by Panda et al. (1978) varied from 0.1602 to $0.4789 \mathrm{mg} \mathrm{L}^{-1}$ $\mathrm{min}^{-1}$, and RR and PVd were the soils with the minimum and maximum kinetics of $\mathrm{P}$ adsorption, respectively (Table 3). At an initial $\mathrm{P}$ concentration of $60 \mathrm{mg} \mathrm{L}^{-1}$, sorption rates were highest in the PA and PVA soils (0.0897 and $\left.0.0890 \mathrm{mg} \mathrm{L}^{-1} \mathrm{~min}^{-1}\right)$ and lowest in the RR and RY soils $\left(0.0122\right.$ and $0.0109 \mathrm{mg} \mathrm{L}^{-1}$ $\mathrm{min}^{-1}$ ), respectively. It is important to stress that the initial content of available P was lowest in the PA and highest in the RY soil (Table 1), which may indicate lower and higher saturation of the $\mathrm{P}$ adsorption sites in these soils.

The values of the coefficient $n$ of the equation of Panda et al. (1978) obtained were two and ten times lower than those observed by Gonçalves et al. (1985), at the low and high initial $\mathrm{P}$ concentration, demonstrating the lower capacity of $\mathrm{P}$ sorption in the soils of Paraíba compared to the Cerrado soils and, consequently, a lower P sorption rate. Unlike in the Cerrado, P sorption in soils in the semiarid region of northeast Brazil is low and the doses of phosphate fertilizers required to maintain an adequate level of $\mathrm{P}$ in the soil solution to ensure plant growth are not high (Agbenin \& Tiessen, 1994; Pereira \& Faria, 1998; Farias et al., 2009).

The K values in the equation proposed by Barrow \& Shaw (1975), which represent the $\mathrm{P}$ sorption kinetics, varied from 0.0507 in VX to 0.0032 in RR soil, at the lower initial $\mathrm{P}$ concentration in the equilibrium solution, indicating higher sorption kinetics in VX than in RR soil. This tendency was confirmed in an assessment of the $\mathrm{n}$ values, which control the reaction rate at constant concentration; the lowest $\mathrm{n}$ values, as observed in the VX soil at both initial $\mathrm{P}$ concentration, indicate that in this soil the reaction is faster in the beginning, but tends to slow down with time (Barrow, 1983a). 
According to the equation proposed by Kuo \& Lotse (1974), the soils with highest and lowest P sorption rates, detected by the $K$ values, were VX and $R R$ (0.0082 and $0.0001 \mathrm{mg} \mathrm{L}^{-1} \mathrm{~min}^{-1}$, respectively). A similar trend was observed when the initial $\mathrm{P}$ concentration was $60 \mathrm{mg} \mathrm{L}^{-1}$ (Table 3). A comparison of the equations showed the lowest sorption rate in $\mathrm{RR}$, soil, and the highest in VX soil, based on the equations proposed by Barrow \& Shaw (1975) and Kuo \& Lotse (1974), and on the equation suggested by Panda et al. (1978) for the PVA soil.

The coefficients of the equations were correlated to soil properties, and at the lower initial concentration, positive correlations were observed between the constants of the studied equations and soil properties such as cation exchange capacity (CEC), dithionite $\mathrm{Fe}\left(\mathrm{Fe}_{\mathrm{d}}\right)$, MPAC, clay content and $\mathrm{P}$ adsorbed after $24 \mathrm{~h}$, and negative correlations with remaining $\mathrm{P}$ (Table 4). These properties reflect the $\mathrm{P}$ sorption rate in the soil best and can be used as sorption indices. Results are similar at the higher initial $\mathrm{P}$ concentration (Table 4). It is important to stress that, depending on the equation, one given soil property shows better results than others. Soil CEC, e.g., was only correlated with the $\mathrm{n}$ of the equation proposed by
Panda et al. (1978), at both concentrations, whereas $\mathrm{Fe}_{\mathrm{d}}$ correlated only with $\mathrm{K}$ of the equation proposed by Kuo \& Lotse (1974), at the lower initial P concentration. CEC was closely correlated with maximum $\mathrm{P}$ sorption in the study of Singh et al. (1983). The explanation suggested by the authors is that $\mathrm{P}$ sorption would occur by the sharing of valence electrons of exchangeable cations, particularly of $\mathrm{Fe}$ and $\mathrm{Al}$, among the micelles on the clay surface and the phosphate ions.

In this study, positive correlations were observed between dithionite $\mathrm{Al}\left(\mathrm{Al}_{\mathrm{d}}\right)$ and oxalate $\mathrm{Al}\left(\mathrm{Al}_{\mathrm{o}}\right)$ and the constant $\mathrm{n}$ of the equation of Panda et al. (1978) at both initial $\mathrm{P}$ concentrations. Iron oxalate $\left(\mathrm{Fe}_{\mathrm{o}}\right)$ was not correlated with the coefficients of either of the two initial $\mathrm{P}$ concentrations (Table 4).

On the other hand, in the study of Barrow (1980), involving a wide variety of soils, no correlations were found between the constant $\mathrm{n}$ of the equation proposed by Barrow \& Shaw (1975) and $\mathrm{Fe}_{\mathrm{d}}$ and $\mathrm{P}$ adsorbed after 24 hours, as also observed in the present study, at both initial $\mathrm{P}$ concentrations (Table 4). However, regarding the MPAC and the clay content, there were significant correlations at the lower $\mathrm{P}$ concentration, suggesting that these soil properties can be used as

Table 4. Coefficients of simple linear correlation between the coefficients of the studied equations and soil properties

\begin{tabular}{|c|c|c|c|c|c|c|c|}
\hline \multirow{3}{*}{ Soil property } & \multicolumn{7}{|c|}{ Coefficient } \\
\hline & \multicolumn{2}{|c|}{ Panda et al. (1978) ${ }^{(1)}$} & \multicolumn{3}{|c|}{ Barrow \& Shaw (1975) } & \multicolumn{2}{|c|}{ Kuo \& Lotse $(1974)^{(3)}$} \\
\hline & $\mathbf{K}$ & $\mathbf{n}$ & $\mathbf{K}$ & $\mathbf{m}$ & $\mathbf{n}$ & $\mathbf{K}$ & $\mathbf{M}$ \\
\hline & \multicolumn{7}{|c|}{ Initial $\mathrm{P}$ concentration of $6 \mathrm{mg} \mathrm{L}^{-1}$} \\
\hline CEC & $-0.28^{\mathrm{ns}}$ & $0.54^{+}$ & $0.37^{\mathrm{ns}}$ & $0.38^{\mathrm{ns}}$ & $-0.34^{\mathrm{ns}}$ & $0.46^{\mathrm{ns}}$ & $0.30^{\mathrm{ns}}$ \\
\hline P-rem & $0.85^{* *}$ & $-0.84^{* *}$ & $-0.94^{* * *}$ & $-0.26^{\mathrm{ns}}$ & $0.89^{* *}$ & $-0.97^{* *}$ & $-0.87^{* *}$ \\
\hline $\mathrm{Fe}_{\mathrm{d}}$ & $-0.44^{\mathrm{ns}}$ & $0.43^{\mathrm{ns}}$ & $0.46^{\mathrm{ns}}$ & $0.30^{\mathrm{ns}}$ & $-0.46^{\mathrm{ns}}$ & $0.53^{+}$ & $0.24^{\mathrm{ns}}$ \\
\hline $\mathrm{Fe}_{0}$ & $-0.47^{\mathrm{ns}}$ & $0.13^{\mathrm{ns}}$ & $0.04^{\mathrm{ns}}$ & $0.38^{\mathrm{ns}}$ & $-0.03^{\mathrm{ns}}$ & $0.11^{\mathrm{ns}}$ & $0.13^{\mathrm{ns}}$ \\
\hline $\mathrm{Al}_{\mathrm{d}}$ & $-0.18^{\mathrm{ns}}$ & $0.65^{*}$ & $-0.60^{\mathrm{ns}}$ & $0.01^{\mathrm{ns}}$ & $0.60^{*}$ & $-0.59^{*}$ & $-0.46^{\mathrm{ns}}$ \\
\hline $\mathrm{Al}_{\mathrm{o}}$ & $-0.76^{* *}$ & $0.77^{* *}$ & $0.23^{\mathrm{ns}}$ & $0.12^{\mathrm{ns}}$ & $-0.11^{\mathrm{ns}}$ & $0.25^{\mathrm{ns}}$ & $0.49^{+}$ \\
\hline CMAP & $-0.86^{* *}$ & $0.81^{* *}$ & $0.93^{*}$ & $0.27^{\mathrm{ns}}$ & $-0.86^{* *}$ & $0.97^{* *}$ & $0.92^{* *}$ \\
\hline Silt & $-0.72^{* *}$ & $0.01^{\mathrm{ns}}$ & $0.62^{*}$ & $-0.37^{\mathrm{ns}}$ & $-0.61^{*}$ & $0.49^{\mathrm{ns}}$ & $0.56^{+}$ \\
\hline Clay & $-0.82^{* *}$ & $0.64^{*}$ & $0.86^{* *}$ & $0.08^{\mathrm{ns}}$ & $-0.80^{* *}$ & $0.85^{* *}$ & $0.87^{* *}$ \\
\hline \multirow[t]{2}{*}{$\mathrm{P}$ ads. ${ }^{(4)}$} & $-0.15^{\mathrm{ns}}$ & $0.81^{* *}$ & $0.28^{\mathrm{ns}}$ & $0.89^{* *}$ & $-0.23^{\mathrm{ns}}$ & $0.49^{\mathrm{ns}}$ & $0.37^{\mathrm{ns}}$ \\
\hline & \multicolumn{7}{|c|}{ Initial $\mathrm{P}$ concentration of $60 \mathrm{mg} \mathrm{L}^{-1}$} \\
\hline CEC & $-0.09^{\mathrm{ns}}$ & $0.51^{+}$ & $-0.36^{\mathrm{ns}}$ & $0.39^{\mathrm{ns}}$ & $-0.14^{\mathrm{ns}}$ & $-0.04^{\mathrm{ns}}$ & $-0.009^{n s}$ \\
\hline P-rem & $0.60^{*}$ & $-0.65^{*}$ & $0.51^{+}$ & $-0.61^{*}$ & $0.36^{\mathrm{ns}}$ & $-0.63^{*}$ & $-0.46^{\mathrm{ns}}$ \\
\hline $\mathrm{Fe}_{\mathrm{d}}$ & $0.10^{\mathrm{ns}}$ & $0.55^{+}$ & $-0.28^{\mathrm{ns}}$ & $0.36^{\mathrm{ns}}$ & $0.02^{\mathrm{ns}}$ & $0.01^{\mathrm{ns}}$ & $-0.13^{\mathrm{ns}}$ \\
\hline $\mathrm{Fe}_{0}$ & $-0.25^{\mathrm{ns}}$ & $0.10^{\mathrm{ns}}$ & $-0.28^{\mathrm{ns}}$ & $0.29^{\mathrm{ns}}$ & $-0.44^{\mathrm{ns}}$ & $0.11^{\mathrm{ns}}$ & $0.18^{\mathrm{ns}}$ \\
\hline $\mathrm{Al}_{\mathrm{d}}$ & $0.09^{\mathrm{ns}}$ & $0.69^{*}$ & $0.08^{\mathrm{ns}}$ & $-0.11^{\mathrm{ns}}$ & $0.18^{\mathrm{ns}}$ & $-0.46^{\mathrm{ns}}$ & $-0.29^{\mathrm{ns}}$ \\
\hline $\mathrm{Al}^{\mathrm{d}}$ & $-0.66^{*}$ & $0.56^{+}$ & $-0.15^{\mathrm{ns}}$ & $0.19^{\mathrm{ns}}$ & $-0.36^{\mathrm{ns}}$ & $0.51^{+}$ & $0.49^{\mathrm{ns}}$ \\
\hline CMAP & $-0.64^{*}$ & $0.62^{*}$ & $-0.53^{+}$ & $0.63^{*}$ & $-0.37^{\mathrm{ns}}$ & $0.72^{* *}$ & $0.53^{+}$ \\
\hline Silt & $-0.73^{* *}$ & $-0.15^{\mathrm{ns}}$ & $-0.21^{\mathrm{ns}}$ & $0.26^{\mathrm{ns}}$ & $-0.69^{*}$ & $0.62^{*}$ & $0.86^{* *}$ \\
\hline Clay & $-0.70^{*}$ & $0.42^{\mathrm{ns}}$ & $-0.43^{\mathrm{ns}}$ & $0.53^{+}$ & $-0.41^{\mathrm{ns}}$ & $0.80^{* *}$ & $0.60^{*}$ \\
\hline $\mathrm{P}$ ads. ${ }^{(4)}$ & $-0.21^{\mathrm{ns}}$ & $0.92^{* *}$ & $-0.55^{+}$ & $0.67^{*}$ & $0.15^{\mathrm{ns}}$ & $0.45^{\mathrm{ns}}$ & $0.15^{\mathrm{ns}}$ \\
\hline
\end{tabular}

(1) $\mathrm{C}=\mathrm{K} \mathrm{t}^{-\mathrm{n}}$, C:concentration in time $\mathrm{t}, \mathrm{K}$ : constant related to $\mathrm{P}$ in the solution, $\mathrm{n}$ : constant related to the sorption rate. ${ }^{(2)} \mathrm{X}=\mathrm{K}$ $\mathrm{C}^{\mathrm{m}} \mathrm{t}^{\mathrm{n}}, \mathrm{X}$ : $\mathrm{P}$ adsorbed, $\mathrm{C}: \mathrm{P}$ concentration in time $\mathrm{t}, \mathrm{K}, \mathrm{m}$ and $\mathrm{n}$ are constant. (3) $\mathrm{X}=\mathrm{K} \mathrm{Co} \mathrm{t}^{1 / \mathrm{m}}, \mathrm{X}$ : $\mathrm{P}$ adsorbed, Co: initial $\mathrm{P}$ concentration, $\mathrm{K}$ : sorption rate, m: non-dimensional constant. ${ }^{(4)} \mathrm{P}$ adsorbed after $24 \mathrm{~h} .{ }^{* * *},{ }^{+}$and ns, significant at 1 , 5 and $10 \%$ and non significant by $\mathrm{T}$ test, respectively. 
indicators of the $\mathrm{P}$ sorption rates in soils of the state of Paraíba, only at low $\mathrm{P}$ concentrations. Nevertheless, P-rem can be used as indicator of the sorption rate at both initial $\mathrm{P}$ concentrations. Another important observation is that the $\mathrm{n}$ values were negatively correlated with silt contents at both initial P concentrations (Table 4).

According to the referred data, at the lower initial $\mathrm{P}$ content $\left(6 \mathrm{mg} \mathrm{L}^{-1}\right)$ the differences between soils are very noticeable, and it is possible to distinguish the soils that adsorb most $\mathrm{P}$ in the shortest time. On the other hand, at the higher initial $\mathrm{P}$ concentration (60 $\mathrm{mg} \mathrm{L}^{-1}$ ) the difference between soils concerning $\mathrm{P}$ sorption cannot be easily detected, perhaps because this amount of $\mathrm{P}$ is excessive for the soils of Paraíba, which are characterized by low contents of $\mathrm{Fe}$ and $\mathrm{Al}$ oxides, low MPAC and high P-rem. According to the above findings, the use of a P concentration of $60 \mathrm{mg} \mathrm{L}^{-1}$ to determine remaining $\mathrm{P}$ (Alvarez V. et al., 2000) is high and inadequate for these soils. Therefore, further studies are needed to indicate the most suitable initial $\mathrm{P}$ concentration for the determination of $\mathrm{P}$-rem in soils of the State of Paraíba and northeastern Brazil, which have lower MPAC values than soils in other Brazilian regions.

The values of AICc (Akaike's corrected Information Criterion) (Table 5) indicated that the data fit best to the equation proposed by Kuo \& Lotse (1974), at the lower initial $\mathrm{P}$ concentration. For the higher concentration, this equation had a better performance than the others in the PAC, RY, PVA and PVe soils, whereas the data from the RL, PA, LA, TX, SX, PVd and VX soils fit best to the equation proposed by Barrow \& Shaw (1975) (Table 5). Guan et al. (2007) also observed that the data fit best to the equation of Kuo \& Lotse (1974) in their assessment of P sorption kinetics in sediments.

The three equations of this study were based on the Freundlich equation, and in the equation proposed by Kuo \& Lotse (1974) the Freundlich equilibrium constant is expressed as an empirical function of time. The use of these equations presupposes that the amount of phosphate adsorbed decreases over time, and that the phosphate adsorbed is in equilibrium

Table 5. Values of Akaike's corrected Information Criterion (AICc) and coefficients of determination for equations used in the description of the $P$ sorption kinetics at two initial $P$ concentrations in soil solution

\begin{tabular}{|c|c|c|c|c|c|c|}
\hline \multirow{3}{*}{ Soil $^{(1)}$} & \multicolumn{6}{|c|}{ Equation } \\
\hline & \multicolumn{2}{|c|}{ Panda et al. (1978) ${ }^{(2)}$} & \multicolumn{2}{|c|}{ Barrow \& Shaw (1975) } & \multicolumn{2}{|c|}{ Kuo \& Lotse (1974) ${ }^{(4)}$} \\
\hline & AICc & $\mathbf{R}^{2}$ & AICc & $\mathbf{R}^{2}$ & $\mathrm{AICc}$ & $\mathbf{R}^{2}$ \\
\hline & \multicolumn{6}{|c|}{ Initial $\mathrm{P}$ concentration of $6 \mathrm{mg} \mathrm{L}^{-1}$} \\
\hline $\mathrm{RR}$ & 3.75 & 0.69 & -115.91 & 0.96 & -117.78 & 0.95 \\
\hline $\mathrm{RL}$ & -5.18 & 0.84 & -124.03 & 0.98 & -128.45 & 0.98 \\
\hline PAC & -4.28 & 0.87 & -126.95 & 0.99 & -131.46 & 0.99 \\
\hline $\mathrm{RY}$ & -27.85 & 0.93 & -107.03 & 0.97 & -134.51 & 0.96 \\
\hline $\mathrm{PA}$ & -10.49 & 0.90 & -111.78 & 0.94 & -114.50 & 0.92 \\
\hline LA & -15.63 & 0.92 & -126.77 & 0.98 & -128.99 & 0.97 \\
\hline $\mathrm{TX}$ & -20.39 & 0.93 & -124.17 & 0.96 & -129.07 & 0.96 \\
\hline $\mathrm{SX}$ & -31.58 & 0.94 & -129.83 & 0.95 & -135.02 & 0.95 \\
\hline PVA & -39.29 & 0.97 & -114.38 & 0.80 & -119.62 & 0.80 \\
\hline PVe & -36.45 & 0.97 & -128.82 & 0.96 & -131.54 & 0.95 \\
\hline PVd & -44.14 & 0.96 & -128.38 & 0.87 & -133.59 & 0.87 \\
\hline \multirow[t]{2}{*}{$\mathrm{VX}$} & -67.34 & 0.98 & -133.63 & 0.82 & -137.88 & 0.80 \\
\hline & \multicolumn{6}{|c|}{ Initial $\mathrm{P}$ concentration of $60 \mathrm{mg} \mathrm{L}^{-1}$} \\
\hline $\mathrm{RR}$ & 16.82 & 0.40 & -93.78 & 0.84 & -84.90 & 0.42 \\
\hline $\mathrm{RL}$ & 16.99 & 0.65 & -112.90 & 0.98 & -87.45 & 0.74 \\
\hline PAC & 19.86 & 0.63 & -100.00 & 0.96 & -133.20 & 0.66 \\
\hline RY & 14.33 & 0.34 & -79.21 & 0.16 & -86.82 & 0.33 \\
\hline PA & 34.75 & 0.82 & -86.94 & 0.98 & -82.34 & 0.96 \\
\hline LA & 12.70 & 0.93 & -88.70 & 0.95 & -64.55 & 0.93 \\
\hline $\mathrm{TX}$ & 17.45 & 0.73 & -109.30 & 0.98 & -86.03 & 0.78 \\
\hline $\mathrm{SX}$ & 18.06 & 0.90 & -83.01 & 0.94 & -81.74 & 0.88 \\
\hline PVA & 13.09 & 0.96 & -136.80 & 0.97 & -138.60 & 0.96 \\
\hline PVe & 13.96 & 0.93 & -89.84 & 0.96 & -137.90 & 0.93 \\
\hline PVd & 14.90 & 0.91 & -94.56 & 0.97 & -88.68 & 0.93 \\
\hline VX & 11.74 & 0.88 & -160.50 & 0.87 & -137.50 & 0.85 \\
\hline
\end{tabular}

(1) RR: Neossolo Regolítico, RL: Neossolo Litólico, PAC: Argissolo Acinzentado, RY: Neossolo Flúvico, PA: Argissolo Amarelo, LA: Latossolo Amarelo, TX: Luvissolo Háplico, SX: Planossolo Háplico, PVA: Argissolo Vermelho-Amarelo; PVe: Argissolo Vermelho eutrófico, PVd: Argissolo Vermelho distrófico, VX: Vertissolo Háplico. ${ }^{(2)}$ Panda et al. (1978), C $=$ K t ${ }^{-n}$. (3) Barrow \& Shaw (1975), $\mathrm{X}=\mathrm{K} \mathrm{C}^{\mathrm{m}} \mathrm{t}^{\mathrm{n}} \cdot{ }^{(4)}$ Kuo \& Lotse (1974), $\mathrm{X}=\mathrm{K}$ Co $\mathrm{t}^{1 / \mathrm{m}}$. 
with phosphate in the solution. If this assumption is met, the equation can be described by Freundlich equation presented by Barrow \& Shaw (1975), who describe the tridimensional relation between sorption, concentration and time. In their modification of this equation, Kuo \& Lotse (1974) describe the bidimensional relation between sorption and time for each initial P concentration (Mendoza \& Barrow, 1987). This may explain why this equation best fit the data of the present study.

Due to the non-homogeneous chemical and mineral composition of the soils, particularly at the surface, and to the occurrence of variable morphologies and dimensions in the same soil material, it is difficult to establish an equation that reasonably describes the dynamics of ions in the mineral phase (Reis et al., 1995). Thus, most equations used are empirical and do not contain enough information to describe the entire process of $\mathrm{P}$ sorption of the soil (Cheung \& Venkitachalam, 2006; Guan et al., 2007). However, there are deterministic equations that consider the processes involved in $\mathrm{P}$ sorption, adsorption and precipitation, besides diffusion. The disadvantage of these equations is the need for a great number of data such as $\mathrm{pH}$, electrolytic composition and description of the solid surface properties. It is rather difficult to obtain these data, since the solid state variables, such as the charge or potential of the surface differ for the different components of the solid phase (clay, Fe and $\mathrm{Al}$ oxides and organic matter), whereas the concentration of relevant ions in the solution varies over time (Barrow, 1983b; van der Zee \& Gjaltema, 1992).

\section{CONCLUSIONS}

1. The $\mathrm{P}$ sorption kinetics in soils with high MPAC and low P-rem was fast in the first $30 \mathrm{~min}$ at the lower initial $\mathrm{P}$ concentration $\left(6 \mathrm{mg} \mathrm{L}^{-1}\right)$, and it was not possible to detect many differences between soils at the higher initial concentration $\left(60 \mathrm{mg} \mathrm{L}^{-1}\right)$.

2 . The $\mathrm{P}$ sorption rate is directly related to the clay content, the MPAC and the $\mathrm{Fe}_{\mathrm{d}}$ of soils.

3. The data of most soils fitted the equation of Kuo and Lotse, and, thus, its coefficients can be used to predict the rate of soil $\mathrm{P}$ adsorption.

\section{LITERATURE CITED}

AGBENIN, J.O. \& TIESSEN, H. The effects of soil properties on the differential phosphate sorption by semiarid soils from Northeast Brazil. Soil Sci., 157:36-45, 1994.

AKAIKE, H. A new look at the statistical model identification. IEEE Trans. Autom. Control., 19:716-723, 1974.
ALVAREZ V., V.H.; NOVAIS, R.F.; DIAS, L.E. \& OLIVEIRA, J.A. Determinação e uso do fósforo remanescente. B. Inf. SBCS, 25:27-32, 2000.

BARROW, N.J. Effect of previous additions of phosphate on phosphate adsorption by soils. Soil Sci., 118:82-89, 1974.

BARROW, N.J. Differences amongst a wide-ranging collection of soils in the rate of reaction with phosphate. Austr. J. Soil Res., 18:215-224, 1980.

BARROW, N.J. A discussion of the methods for measuring the rate of reaction between soil and phosphate. Fert. Res., 4:51-61, 1983a.

BARROW, N.J. A mechanistic model for describing the sorption and desorption of phosphate by soil. J. Soil Sci., 34:733$750,1983 b$.

BARROW, N.J. \& SHAW, T.C. The slow reactions between soil and anions: 2. Effect of time and temperature on the decrease in phosphate concentration in the soil solution. Soil Sci., 119:167-177, 1975.

BRAGA, J.M. \& DEFELIPO, B.V. Determinação espectrofotométrica de fósforo em extratos de solo e material vegetal. R. Ceres, 21:73-85, 1974.

CHAVES, L.H.G.; CHAVES, I.B. \& MENDES, J.S. Adsorção de fósforo em materiais de Latossolo e Argissolo. R. Caatinga, 20:104-111, 2007.

CHEUNG, K.C. \& VENKITACHALAM, T.H. Kinetic studies on phosphorus sorption by selected soil amendments for septic tank effluent renovation. Environ. Geochem. Health, 28:121-131, 2006.

CHIEN, S.H. \& CLAYTON, W.R. Application of Elovich equation to the kinetics of phosphate release and sorption in soils. Soil Sci. Soc. Am. J., 44:265-268, 1980.

EMPRESA BRASILEIRA DE PESQUISA AGROPECUÁRIA EMBRAPA. Centro Nacional de Pesquisa do Solo. Sistema brasileiro de classificação de solos. 2.ed. Rio de Janeiro, Embrapa Solos, 2006. 306p.

EMPRESA BRASILEIRA DE PESQUISA AGROPECUÁRIA EMBRAPA. Centro Nacional de Pesquisa do Solo. Manual de métodos de análise de solo. Rio de Janeiro, 1997. 212p.

FARIAS, D.R.; OLIVEIRA, F.H.T.; SANTOS, D.; ARRUDA, J.A.; HOFFMANN, R.B. \& NOVAIS, R.F. Fósforo em solos representativos do Estado da Paraíba. I. Isotermas de adsorção e medidas do fator capacidade de fósforo. R. Bras. Ci. Solo, 33:623-632, 2009.

GODINHO, V.P.C.; SAMPAIO, R.A.; ALVAREZ V., V.H. \& RUIZ, H.A. Adsorção de fosfato em três solos da região semi-árida do Rio Grande do Norte. Pesq. Agropec. Bras., 32:819-823, 1997.

GONÇALVES, J.L.M.; FIRME, D.J.; NOVAIS, R.F. \& RIBEIRO, A.C. Cinética de adsorção de fósforo em solos de Cerrado. R. Bras. Ci. Solo, 9:107-111, 1985.

GUAN, X.; CHEN, G. \& SHANG, C. Adsorption behaviour of condensed phosphate on aluminium hydroxide. J. Environ. Sci., 19:312-318, 2007. 
KARACA, S.; GURSES, A.; EJDER, M. \& AÇIKYILDIZ, M. Kinetic modelling of liquid-phase adsorption of phosphate on dolomite. J. Colloid Interface Sci., 277:257-263, 2004.

KUO, S. \& LOTSE, E.G. Kinetics of phosphate adsorption and desorption by hematite and gibbsite. Soil Sci., 116:400406, 1974.

LUENGO, C.; BRIGANTE, M. \& AVENA, M. P adsorption kineticshosphate and arsenate on goethite. A compatative study. J. Colloid Interface Sci., 311:354-360, 2007.

MENDOZA, R.E. \& BARROW, N.J. Characterizing the rate of reaction of some Argentinean soils with phosphate. Soil Sci., 148:105-112, 1987.

MOREIRA, F.L.M.; MOTA, F.O.B.; CLEMENTE, C.A.; AZEVEDO, B.M. \& BOMFIN, G.V. Adsorção de fósforo em solos do Estado do Ceará. R. Ci. Agron., 37:7-12, 2006.

NOVAIS, R.F. \& SMYTH, T.J. Fósforo em solo e planta em condições tropicais. Viçosa, MG, Universidade Federal Viçosa, 1999. 399p.

OLIVEIRA, F.H.T.; LEAL, J.V.; SANTOS, D.; FARIAS, D.R. \& ARRUDA, J.A. Banco de solos representativos do Estado da Paraíba. In: REUNIÃO BRASILEIRA DE MANEJO E CONSERVAÇÃO DO SOLO E DA ÁGUA, 16., Aracaju, 2006. Anais... Aracaju, SBCS/UFSE, 2006. CD ROM.

PANDA, D.; MOHAPATRA, J.S.; MISRA, C. \& PANDA, N. Movement and retention of phosphate in Lateritic soil cores. J. Indian Soc. Soil Sci., 26:25-32, 1978.

PEREIRA, J.R. \& FARIA, C.M.B. Sorção de fósforo em alguns solos do Semi-árido do Nordeste brasileiro. Pesq. Agropec. Bras., 33:1179-1184, 1998.
POLYZOPOULOS, N.A.; KERAMIDAS, V.Z. \& PAVLATOV, A. On the limitations of the simplified Elovich equation in describing the kinetic of phosphate sorption and release from soils. J. Soil Sci., 37:81-87, 1986.

REIS, C.; FABRIS, J.D.; NOVAIS, R.F.; BAHIA FILHO, A.F.C.; SANTANA, D.P.; CURI, N. \& COEY, J.M.D. Cinética de sorção de fósforo em alguns solos de Minas Gerais. R. Bras. Ci. Solo, 19:337-344, 1995.

SAEG. Sistema para análises estatísticas. Versão 9.1. Viçosa, MG, Fundação Arthur Bernardes, 2007.

SIMS, J.T. \& PIERZYNSKI, G.M. Chemistry of phosphorus in soils. In: TABATABAI, M.A. \& SPARKS, D.L. Chemical processes in soils. Madison, Soil Science Society of America, 2005. p.151-192.

SINGH, R.; MOLLER, M.R.F. \& FERREIRA, W.A. Cinética de sorção de fósforo em solos dos trópicos úmidos da Amazônia. R. Bras. Ci. Solo, 7:227-231, 1983.

SPARKS, D.L. Environmental soil chemistry. New York, Academic Press, 1995.

TORRENT, J. Rapid and slow phosphate sorption by Mediterranean soils: Effect of ions oxides. Soil Sci. Soc. Am. J., 51:78-82, 1987.

van der ZEE, S. \& GJALTEMA, A. Simulation of phosphate transport in soil columns. I. Model development. Geoderma, 52:87-109, 1992.

WANG, Y.; SHEN, A.; NIU, J. \& LIU, R. Adsorption of phosphorus on sediments from the Three-Gorges Reservoir (China) and the relation with sediment compositions. J. Hazard. Mater., 162:92-98, 2009. 